S.C.S. Cunha:

https://orcid.org/0000-0002-3533-5199 M.M. André:

(0000-0002-9363-2458 K.B. Corgozinhe:

K.B. Corgozinho:
https://orcid.org/0000-0002-6648-4533 https://orcid.org/

\section{Radiation therapy for advanced canine nasal planum squamous cell} carcinoma: case report

\author{
[A utilização da radioterapia no tratamento do carcinoma de células escamosas \\ de plano nasal canino avançado: relato de caso] \\ S.C.S. Cunha ${ }^{1}$, M.M. André ${ }^{2}$, K.B. Corgozinho ${ }^{3}$, K.V.G.C. Silva ${ }^{4}$, \\ C.A. Silva ${ }^{1}$, A.M.R. Ferreira ${ }^{4}$ \\ ${ }^{1}$ Aluno de pós-graduação - Universidade Federal Fluminense - Niterói, RJ \\ ${ }^{2}$ Oncopet Veterinária - Rio de Janeiro, RJ \\ ${ }^{3}$ Universidade Federal Rural do Rio de Janeiro - Seropédica, RJ \\ ${ }^{4}$ Universidade Federal Fluminense - Niterói, RJ
}

https://orcid.org/0000-0002-5698-7495 C.A. Silva:

https://orcid.org/0000-0002-1096-225X A.M.R. Ferreira:

https://orcid.org/0000-0001-6345-1106

\begin{abstract}
This case report describes the outcome of treatment of dogs with advanced (deeply invasive) nasal planum squamous cell carcinomas with palliative or definitive radiation therapy. All dogs were diagnosed with nasal planum squamous cell carcinoma by histopathology, and their owners declined aggressive surgery. Dogs were treated with a cobalt-60 unit, definitive-intent radiation protocol consisting of 15 daily fractions (Monday-Friday) of $2.8 \mathrm{~Gy}$, and palliative radiation protocol consisting of 4 fractions of 8 Gy performed once a week. Three $\operatorname{dogs}$ had $\mathrm{T}_{3}$ tumors and three had $\mathrm{T}_{4}$ tumors according to the WHO staging system. Two dogs had tumor complete remission and four had tumor partial remission. Survival time of dogs submitted to radiation therapy was 95-417 days. Radiation acute side effects involved only mild epilation and cutaneous erythema in palliative protocols, and moist desquamation, epilation, mild rhinitis and oral mucositis in definitive-intent RT. Radiation therapy, especially palliative protocols, can be a treatment option for nasal planum squamous cell carcinoma in dogs, when the owner declines aggressive surgery. It may contribute to partial or complete tumor remission and better patient quality of life, even at advanced stages, leading to mild side effects.
\end{abstract}

Keywords: canine, squamous cell carcinoma, oncology, radiation therapy

\title{
RESUMO
}

Este relato descreve seis casos de carcinoma de células escamosas de plano nasal canino tratados com radioterapia definitiva ou paliativa. Em todos os casos, o diagnóstico definitivo foi feito mediante biópsia, e os tutores declinaram da cirurgia agressiva. A radioterapia foi realizada utilizando-se um equipamento de cobalto-60, e o protocolo definitivo consistiu de 15 frações de 2,8 Gy, cinco vezes por semana (segunda a sexta), enquanto o protocolo paliativo consistiu de quatro frações de 8 Gy, uma vez. por semana. Seis cães foram tratados, entre os quais três tinham tumores em estágio T3 e três em estágio T4, de acordo com a tabela TNM da Organização Mundial da Saúde. Dois animais apresentaram remissão completa do tumor após o tratamento e quatro apresentaram remissão parcial. $O$ tempo de sobrevida variou entre 95-417 dias, sendo que dois animais ainda estão vivos e em observação. Os efeitos colaterais da radioterapia foram apenas epilação e eritema leve, no protocolo paliativo, $e$ epilação, radiodermite úmida, rinite e mucosite oral, no protocolo definitivo. A radioterapia, especialmente no protocolo paliativo, pode ser considerada uma opção de tratamento quando os tutores declinam da cirurgia agressiva. Ela pode contribuir para remissão (parcial ou completa) do tumor e melhor qualidade de vida do paciente, mesmo nos casos avançados, levando a efeitos colaterais mínimos.

Palavras-chave: canino, carcinoma de células escamosas, oncologia, radioterapia

Recebido em 23 de novembro de 2018

Aceito em 12 de julho de 2019

E-mail: simonecsc@gmail.com 


\section{INTRODUCTION}

In dogs and cats, squamous cell carcinoma (SCC) is the most common nasal planum tumor (Lascelles et al., 2000; Withrow et al., 1990). These tumors may be reported as carcinoma in situ, superficial SCC (<2mm deep) and deeply invasive SCC (Withrow et al., 1990). Clinical signs include erosion and/or ulceration of nasal planum, philtrum, and/or lip or muzzle, and masses can be present or not. Treatment options include surgery, radiation therapy, chemotherapy, or palliative nonsteroidal antiinflammatory drugs (Impellizeri et al., 2008; Séguin et al., 2016; Ter Haar et al., 2015; Thomson, 2007).

Radiation therapy may be a treatment option when owners decline aggressive surgery. Radiation therapy protocols described in previous literature include palliative and definitive (curative-intent) treatment (total doses from 20-48 Gy). However, it rarely provides long-term tumor control. Typically, short-term improvement of the lesion is followed by rapid local tumor regrowth within weeks of completing treatment (Lascelles et al., 2000; Rogers et al., 1995; Larue et al., 2003). This case series reports the outcome of six dogs with deeply invasive nasal planum SCC's treated with palliative or definitive radiation therapy.

\section{CASUISTRY}

Six dogs with histological diagnoses of nasal planum SCC were attended at a private veterinary clinic between October 2016 and May 2018. All dogs had deeply invasive SCC, and their owners declined nosectomy/surgery. There were five labrador retrievers and one golden retriever, with ages ranging from 9 to 13 years. Clinical signs included nostril ulceration, nasal discharge, obstruction of nostrils airflow and inspiratory dyspnea and sneezing (sometimes with nasal bleeding) in all cases. However, in two cases, there was nasal deformation and the tumor was invading the lips.

Overall condition of all dogs was carefully assessed. They were submitted to complete clinical staging, which included primary tumor evaluation, regional lymph node evaluation (by fine needle aspiration), three-view thoracic radiographs, abdominal ultrasonography, and hematological and biochemical examinations.
Clinical staging was performed according to the World Health Organization (Owen, 1980) (Table 1). According to tumor staging, three dogs had T3 tumors and three dogs had T4 tumors. Three dogs had regional lymph node metastases at the time of diagnosis, and one also had probable lung metastasis (pulmonary nodules observed in thoracic radiographs).

Table 1. World Health Organization classification for canine tumors of epidermal origin

\begin{tabular}{cl}
\hline $\mathrm{T}$ & \\
\hline $\mathrm{T}_{0}$ & No evidence of tumor \\
$\mathrm{T}_{\mathrm{is}}$ & Tumor in situ \\
$\mathrm{T}_{1}$ & Tumor $<2 \mathrm{~cm}$ in diameter \\
$\mathrm{T}_{2}$ & Tumor $2-5 \mathrm{~cm}$ in diameter or minimally \\
& invasive \\
$\mathrm{T}_{3}$ & Tumor $>5 \mathrm{~cm}$ in diameter or with invasion of \\
& Vubcutis \\
$\mathrm{T}_{4}$ & Variable diameter; tumor invading fascia, \\
$\mathrm{N}$ & \\
$\mathrm{N}_{0}$ & Absence of lymph node metastasis \\
$\mathrm{N}_{1}$ & Presence of lymph node metastasis \\
$\mathrm{M}$ & \\
$\mathrm{M}_{0}$ & Absence of distant metastasis \\
$\mathrm{M}_{1}$ & Presence of distant metastasis \\
\hline
\end{tabular}

Palliative radiation protocol consisted of four fractions of $8 \mathrm{~Gy}$ performed once a week, for a total of 32 Gy. Definitive-intent radiation protocol consisted of 15 daily fractions (Monday-Friday) of $2.8 \mathrm{~Gy}$, for a total of $42 \mathrm{~Gy}$. Treatment protocol option varied with the general condition of the dog, presence of concomitant diseases, and the owner's treatment decision. If the general condition was good and there was no evidence of regional/distant metastasis, definitive radiation therapy was recommended. Palliative radiation therapy was performed in debilitated dogs and/or with regional/distant metastasis.

The radiation therapy equipment was a cobalt- 60 unit (Theratron 780C, Atomic Energy of Canada Limited, Ontario, Canada). Radiation field size was determined by images obtained from the patient's computed tomography with DICOM viewer software (OsiriX v5.8.5 64-bit, Geneva, Switzerland). Planning target volume included a $3 \mathrm{~cm}$ margin around the macroscopic tumor. Cerrobend blocks were used to protect normal tissue in the radiation field. In all cases, a bolus of $0.5 \mathrm{~mm}$ thickness was used. Source-skindistance was $80 \mathrm{~cm}$, and parallel-opposed fields 
technique was used in all cases. Dogs were anesthetized with $4 \mathrm{mg} / \mathrm{kg}$ propofol (Propofol®, Cristália Produtos Químicos e Farmacêuticos, Brazil) and inhalation anesthetic maintenance was performed with isoflurane (Forane ${ }$, Abbott, USA) via endotracheal tube to ensure correct positioning in all radiation fractions.

Side effects of radiation therapy were graded according to the toxicity criteria of the Veterinary Radiation Therapy Oncology Group (Ladue and Klein, 2001) (Table 2). In palliative radiation therapy, radiation acute side effects involved only mild epilation and cutaneous erythema in the irradiated field (Grade 1), and treatment was not needed. Epilation persisted for 30-45 days after the end of treatment, and the coat grew depigmented and shorter. In definitive radiation therapy, acute side effects included moist desquamation, epilation, mild rhinitis and oral mucositis (Grade 2). In these dogs, supportive treatment (oral analgesics and ecollar) was done. Late effects included skin hyperpigmentation in the irradiated field.

Table 2. Toxicity criteria of the Veterinary Radiation Therapy Oncology Group (Ladue et al., 2001)

\begin{tabular}{|c|c|}
\hline \multicolumn{2}{|l|}{ Acute morbidity } \\
\hline \multirow[t]{4}{*}{ Skin } & 0-No change over baseline \\
\hline & 1-Erythema, dry desquamation, epilation/alopecia \\
\hline & 2-Patchy moist desquamation without edema \\
\hline & 3-Confluent moist desquamation with edema and/or ulceration, necrosis, hemorrhage \\
\hline \multirow{4}{*}{$\begin{array}{l}\text { Mucous } \\
\text { cavity }\end{array}$} & 0 -No change over baseline \\
\hline & 1-Injection without mucositis \\
\hline & 2-Patchy mucositis with patient seemingly pain free \\
\hline & $\begin{array}{l}\text { 3-Confluent fibrinous mucositis necessitating analgesia, ulceration, hemorrhage, } \\
\text { necrosis }\end{array}$ \\
\hline \multirow[t]{4}{*}{ Eye } & 0-No change over baseline \\
\hline & 1-Mild conjunctivitis and/or scleral injection \\
\hline & 2-KCS requiring artificial tears, moderate conjunctivitis or iritis necessitating therapy \\
\hline & 3-Severe keratitis with corneal ulceration and/or loss of vision, glaucoma \\
\hline \multirow[t]{4}{*}{ Ear } & 0-No change over baseline \\
\hline & $\begin{array}{l}\text { 1-Mild external otitis with erythema, pruritus } 2^{\circ} \text { to dry desquamation not requiring } \\
\text { therapy }\end{array}$ \\
\hline & 2-Moderate external otitis requiring topical medication \\
\hline & 3-Severe external otitis with discharge and moist desquamation \\
\hline \multicolumn{2}{|l|}{ Late Morbidity } \\
\hline \multirow[t]{4}{*}{ Skin/Hair } & 0-None \\
\hline & 1-Alopecia, hyperpigmentation, leukotrichia \\
\hline & 2-Asymptomatic induration (fibrosis) \\
\hline & 3-Severe induration causing physical impairment \\
\hline \multirow{4}{*}{ Eye } & 0 -None \\
\hline & 1-Asymptomatic cataracts, KCS \\
\hline & $\begin{array}{l}\text { 2-Symptomatic cataracts, keratitis, corneal ulceration, minor retinopathy, mild to } \\
\text { moderate glaucoma }\end{array}$ \\
\hline & 3-Panophthalmitis, blindness, severe glaucoma, retinal detachment \\
\hline
\end{tabular}

Clinical response to radiation was classified according to the RECIST - Response Evaluation Criteria In Solid Tumors (Eisenhauer et al., 2009) criteria. It was classified as a complete response $(\mathrm{CR})$ when there was a complete tumor remission accompanied by reduction of regional lymph nodes when they were affected; partial response (PR) when there was a regression of at least $30 \%$ of the lesion diameter; stable disease (SD) when there was a decrease of less than $30 \%$ of the lesion diameter, but without progression; and disease progression (DP) when there was progression of at least $20 \%$ of the lesion diameter. Two dogs had tumor complete remission and four had tumor partial remission (Figure 1). In all dogs, the tumor began to reduce during the second week of treatment. One dog with complete remission had tumor recurrence after six months and died of regional and distant metastases after one year of radiation therapy, and the other dog died of unrelated cause (metastatic melanoma) after 95 days of radiation therapy. Of the four dogs with partial remission, one died of unrelated cause (lymphoma) after 


\section{Cunha et al.}

120 days of radiation therapy, one died due to nasal tumor progression after 280 days and the remaining two dogs are still alive. Survival time of dogs submitted to radiation therapy was 95417 days (Table 3 ).

Table 3. Breed, age, gender, stage, treatment, tumor response, survival time and follow-up of six dogs with advanced nasal planum squamous cell carcinoma treated with radiation therapy

\begin{tabular}{|c|c|c|c|c|c|c|c|c|}
\hline Animal & Breed & $\begin{array}{l}\text { Age } \\
\text { (year) }\end{array}$ & Gender & $\begin{array}{l}\text { TNM } \\
\text { Stage } \\
\end{array}$ & Treatment & $\begin{array}{l}\text { RT } \\
\text { Response }\end{array}$ & $\begin{array}{l}\text { Survival } \\
\text { (Days) }\end{array}$ & Follow-up \\
\hline 1 & Labrador & 13 & Male & $\mathrm{T}_{4} \mathrm{~N}_{1} \mathrm{M}_{0}$ & RT 4fx / & PR & 120 & Death - lymphoma \\
\hline 2 & Labrador & 12 & Male & $\mathrm{T}_{3} \mathrm{~N}_{0} \mathrm{M}_{0}$ & RT $15 \mathrm{fx}$ & $\mathrm{CR}$ & 95 & Death - melanoma \\
\hline 3 & Labrador & 12 & Male & $\mathrm{T}_{4} \mathrm{~N}_{1} \mathrm{M}_{0}$ & RT $15 \mathrm{fx}$ & PR & 280 & $\begin{array}{ll}\text { Death } & \text { tumor } \\
\text { progression } & \end{array}$ \\
\hline 4 & Labrador & 13 & Male & $\mathrm{T}_{3} \mathrm{~N}_{0} \mathrm{M}_{0}$ & RT 4 fx / & PR & $417 *$ & Alive \\
\hline 5 & Labrador & 11 & Male & $\mathrm{T}_{4} \mathrm{~N}_{1} \mathrm{M}_{1}$ & RT 4 fx & PR & $205^{*}$ & Alive \\
\hline 6 & $\begin{array}{l}\text { Golden } \\
\text { Retriever }\end{array}$ & 9 & Male & $\mathrm{T}_{3} \mathrm{~N}_{0} \mathrm{M}_{0}$ & RT $15 \mathrm{fx}$ & CR & 350 & $\begin{array}{l}\text { Death } \\
\text { metastasis }\end{array}$ \\
\hline
\end{tabular}

Notes. *Being monitored. $\mathrm{RT}=$ radiation therapy. $\mathrm{fx}=$ radiation fractions. $\mathrm{PR}=$ partial remission. $\mathrm{CR}=$ complete remission.
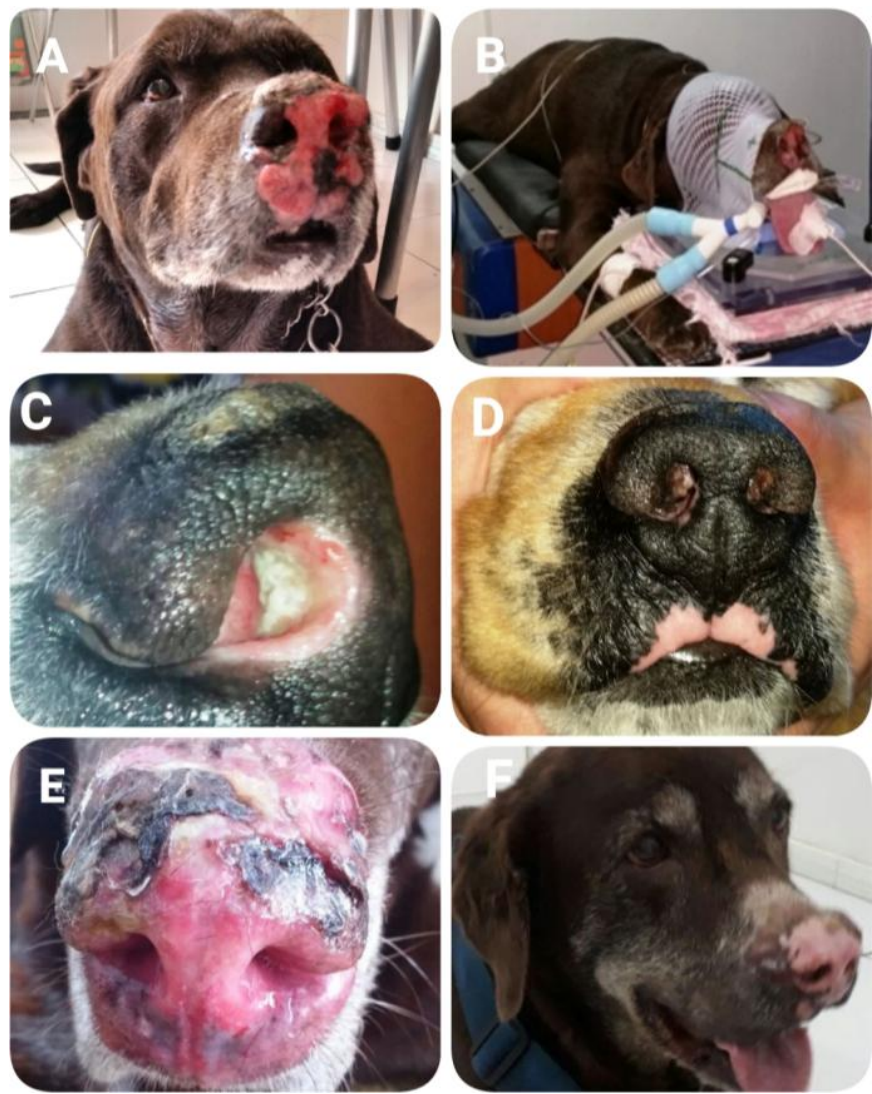

Figure 1. Advanced nasal planum SCC in dogs treated with radiation therapy. A - Nasal deformation and tumor invading nasal philtrum and lips. B - Dog being positioned for radiation therapy. C and D - Canine nasal planum SCC before (C) and after (D) definitive-intent radiation therapy, with complete remission; Note epilation and skin hyperpigmentation in the irradiated field. E and F - Canine nasal planum SCC before $(\mathrm{E})$ and after $(\mathrm{F})$ palliative radiation therapy, with partial remission. 


\section{DISCUSSION}

In previous literature, there are very few reports of radiation therapy for canine nasal planum SCC, which concluded that radiation therapy failed to provide long-term tumor control (Lascelles et al., 2000; Rogers et al., 1995). However, in the present report, 2/6 dogs submitted to radiation therapy had tumor complete remission and $4 / 6$ had tumor partial remission. The survival time of dogs submitted to radiation therapy ranged from 95-417 days, but some dogs are still alive and survival time was not reached yet. All affected dogs were Labrador retrievers and golden retrievers, which are described as predisposed breeds for this tumor in previous articles (Lascelles et al., 2000). In addition, all dogs had tumors originated in the mucous membranes of the nostril, usually with ulceration of nasal planum and nares, as previously described (Lascelles et al., 2000; Withrow and Straw, 1990).

In this report, all dogs had advanced SCC (three dogs had $\mathrm{T}_{3}$ tumors and three had $\mathrm{T}_{4}$ tumors), which indicates aggressive tumor behaviour and late diagnosis. Three dogs already had regional lymph node metastases at the time of diagnosis, and one also had lung metastasis. These findings confirm that this tumor is highly aggressive, especially when there is lymph node metastasis (Lascelles et al., 2000; Withrow and Straw, 1990).

Surgery was declined by owners as most cases were diagnosed in advanced stages (tumors with deep invasion and/or regional lymph node metastasis), and excision of the maxilla and reconstructive procedures would be needed to obtain surgical complete margins (Gallegos et al., 2007; Rogers et al., 1995; Séguin and Steinke, 2016; Ter Haar and Hampel, 2015; Thomson, 2007).

Palliative radiation therapy led to mild epilation and cutaneous erythema in the irradiated field, and definitive radiation therapy to moist desquamation, epilation, mild rhinitis and oral mucositis. In these dogs, only supportive and short duration treatment was needed. These findings are similar to those described in previous literature (Ladue and Klein, 2001; Larue and Gordon, 2013).
Radiation therapy is an important cancer treatment modality in humans and its popularity in veterinary medicine in Brazil has been gradually growing. Radiation therapy, especially palliative protocols, can be a treatment option for nasal planum squamous cell carcinoma in dogs, when aggressive surgery is declined by owner. It may contribute to partial or complete tumor remission and better patient quality of life, especially at advanced stages, leading to mild and self-limiting side effects. Further studies are necessary to better investigate the benefits of palliative radiation therapy for canine nasal planum squamous cell carcinoma.

\section{ACKNOWLEDGEMENT}

The authors thank FAPERJ (Fundação de Amparo à Pesquisa do Estado do Rio de Janeiro).

\section{REFERENCES}

EISENHAUER, E.A.; THERASSE, P.; BOGAERTS, J. et al. New response evaluation criteria in solid tumours: revised RECIST guideline (version 1.1). Eur. J. Cancer, v.45, p.228-247, 2009.

GALLEGOS, J.; SCHMIEDT, C.W., MCANULTY J.F. Cosmetic rostral nasal reconstruction after nasal planum and premaxilla resection: technique and results in two dogs. Vet. Surg., v.36, p.669-674, 2007.

IMPELLIZERI, J. A.; ESPLIN, D.G. Expression of cyclooxygenase-2 in canine nasal carcinomas. Vet. J., v.176, p.408-410, 2008.

LADUE, T.; KLEIN, M.K. Toxicity criteria of the veterinary radiation therapy oncology group. Vet. Radiol. Ultrasound, v.42, p.475-476, 2001.

LARUE, S.M.; GORDON, I.K. Radiation therapy. In: WITHROW, S.J.; MACEWEN, E.G. Small animal clinical oncology. 5.ed. St Louis: Saunders Company, 2013. p.180-197.

LASCELLES, B.D.X.; PARRY, A.T.; STIDWORTHY, M.F. Squamous cell carcinoma of the nasal planum in 17 dogs. Vet. Rec., v.147, p.473-476, 2000.

OWEN, L.N. TNM classification of tumours in domestic animals. Geneva: World Health Organization, 1980. 


\section{Cunha et al.}

ROGERS, K.S.; HELMAN, R.G.; WALKER, M.A. Squamous cell carcinoma of the canine nasal planum: eight cases (1988-1994). J. Am. Anim. Hosp. Assoc., v.31, p.373-378, 1995.

SÉGUIN, B.; STEINKE, J.R. Bilateral superior labial mucosal transposition flaps to correct stenosis of the nares following bilateral rostral maxillectomy combined with nasal planum resection in a dog. Vet. Surg., v.45, p.402-405, 2016.

TER HAAR, G.; HAMPEL, R. Combined rostrolateral rhinotomy for removal of rostral nasal septum squamous cell carcinoma: longterm outcome in 10 dogs. Vet. Surg., v.44, p.843851, 2015.
THOMSON, M. Squamous cell carcinoma of the nasal planum in cats and dogs. Clin. Tech. Small Anim. Pract., v.22, p.42-45, 2007.

WITHROW, S.J.; STRAW, R.C. Resection of the nasal planum in nine cats and five dogs. $J$. Am. Anim. Hosp. Assoc., v.26, p.219-222, 1990. 